\title{
TRACTOR ENGINE LOAD AND FUEL CONSUMPTION IN ROAD CONSTRUCTION WORKS
}

\author{
Algirdas Janulevičius ${ }^{1}$, Antanas Juostas ${ }^{2}$, Gediminas Pupinis ${ }^{3}$ \\ 1, 2, ${ }^{3}$ Lithuanian University of Agriculture, Studentu g. 15, LT-53362 Akademija, Kaunas Region, \\ LithuaniaE-mails: ${ }^{1}$ algirdas.janulevicius@lzuu.lt; ${ }^{2}$ antanas.juostas@kesko.lt; ${ }^{3}$ pupinis@zebra.lt
}

Received 17 April 2010; accepted 15 November 2010

\begin{abstract}
Tractor load influences engine work parameters having an influence on the working economy and productivity of the complete tractor aggregate. The operational economy and productivity of the tractor is mostly evident when its engine power is utilized at least at $80 \%$ and engine speed is as low as possible. The paper analyses the engine parameters of tractor Massey Ferguson MF 8480 during the operational period of road construction works. Control tests on the parameters of the engine load of the tractor engine in combination with the employed milling equipment WS 2500 produced by the company 'Wirtgen' were performed. The study was carried out using engine load tables and graphs collected and stored in the so called ECU Load Profile integrated in Electronic Engine Control Units. Theoretical analysis was made and an equation presented to establish the relation between engine power, engine speed and the quantities of cyclic fuel consumption. The study results present the distribution graphs of work time and fuel consumption at different engine speed during the operational period. The paper also indicates engine load and fuel consumption graphs of the tractor in combination with milling equipment. The article has also disclosed that the analysis of engine speed and load modes using information obtained from tractor-integrated digital microprocessors reveals the operation quality of the tractor.
\end{abstract}

Keywords: tractor, milling equipment, working period, histogram, engine speed, cyclic fuel injection, power, fuel consumption, working time.

\section{Introduction}

The workload and speed of the tractor determine its operating indicators that influence the capacity and efficiency of the whole tractor aggregate as presented by Koval and Samorodov (Коваль, Самородов 2007); Ukhanov et al. (Уханов $u \partial p$. 2009). The operating indicators are engine rotation speed (angular velocity) $w$, torque $M_{e}$, power $P_{e}$, fuel consumption per hour $B_{d}$ and comparative fuel consumption $b_{e}$. The correlation of these indicators is shown by the regulatory performance of the engine. Generally, it is constructed as a rotation speed function. The torque reached by the engine is linearly proportional to the traction power of the tractor and the rotation speed of the crankshaft is proportional to the driving speed of the tractor. Thus, the operating performance of the engine proportionally reflects the performance of the whole tractor (Juostas and Janulevičius 2009a, 2009b; Janulevičius and Juostas 2008; Столбов, Эфрос 2008). Typical operation modes of the tractor engine include idle speed, partial load, nominal load and overload.

The engines having rationally operated tractors work at idle about $10-15 \%$ of the total operation time.
When an aggregate runs unloaded, a partial load of the engine makes about $20-40 \%$ of nominal power and lasts about $15-20 \%$ of the total operation time (Самородов u др. 2004; Столбов, Эфрос 2008). Nominal load approaches make $80-90 \%$ of nominal power and $60-75 \%$ of the total operation time during the technological operation. Engine overloading occurs for short periods when overcoming resistant obstacles. The engine operation period shortens due to the increased load on engine parts, driving speed decreases and aggregate efficiency drops when working under such operation mode as revolutions per minute decrease (Juostas and Janulevičius 2009b; Łazarz et al. 2009; Столбов, Эфрос 2008). Thus, it is irrational to overload the engine.

The performance of the tractor engine depends on the properties of technological operation and conditions for producing an aggregate. Variability in operation conditions and a resulting change in the resistance of working machines constitute variable tractor engine load or a variable operation mode (Pearson and Bevly 2007; Коваль, Самородов 2007). Consequently, to avoid engine overload under production conditions, the engine has to be loaded not that heavily, i.e. some power re- 
serve has to be left and constitute about $6-18 \%$ of full engine power under production conditions (Juostas and Janulevičius 2008; Столбов, Эфрос 2008). Thus, the optimum load level of the tractor engine is $0.82-0.94$. It is recommended to consider the operation conditions of the aggregate when choosing reasonable engine load level for a particular job. When the soil is even, its structure is smooth, and therefore there are no stones or other obstacles which makes possible to choose maximum load level (0.94). When the soil is uneven, its structure erratic, and thus there are a number of obstacles which makes reasonable to choose minimum load level (0.82), as presented by Gorodetsky and Titov (Городецкий, Титов 2008); Stolbov and Efros (Столбов, Эфрос 2008).

The load at any moment is determined by operation conditions at that particular point of time. However, production specificity and the order of technological operation performance are of such nature that there is a need to intensely change engine loading. The tractor aggregate performs technological (functional) work for the major part of time, stands with the running engine some time as well as runs unloaded when turning at the end of the field or running from one field to another. Engine loading is the highest and most variable when performing a technological job when there is a need to sometimes overcome resistant obstacles (Juostas and Janulevičius 2008, 2009a, 2009b; Janulevičius and Juostas 2008; Pearson and Bevly 2007; Raslavičius and Bazaras 2010; Коваль, Самородов 2008; Łazarz et al. 2009; Столбов, Эфрос 2008).

Typical three load modes and the resulting fuel consumption of aggregate appear:

1) during operation when load is nominal or optimal, $B_{d}$;

2) during driving without load when it is partial, $B_{t v}$;

3) at the idle speed of the engine when there is no load, $B_{0}$.

Specific fuel consumption represents fuel consumption corresponding to the engine or traction power of the tractor. Specific fuel consumption shows if the aggregate efficiently consumes fuel. Minimum comparative fuel consumption appears when the engine is fully loaded (power is maximal and revolutions per minute are as small as possible) and the tractor develops the highest traction power (Diesel savings... 2005; Juostas and Janulevičius 2008; Mačiulis et al. 2009; Vantsevich 2008; Городецкий, Титов 2008; Коваль, Самородов 2008).

Analysis reveals that many aggregates are structured without reasonable methodology, irrespective of an optimal operation mode of the tractor. Tractors often work only partially loaded, i.e. using only a part of tractor capacity and traction power. Besides, tractors and their engines operate at idle for some part of the operation period as presented by Juostas and Janulevičius (2009b). There is little data about what part of time tractors have been operating rationally as well as on how efficiently they were operated.

Modern tractors are equipped with hi-tech electronic devices having control on tractor functions and compiled data. The data collected in the integrated digital microprocessors can be examined, transferred to a personal computer or printed using special testing equipment and software. Such databases allow us to study engine load factors during the operational period of the tractor, see Juostas and Janulevičius (2009b); Pranav and Pandey 2008. This study on engine load factors during the operational period of the tractor would give us the possibility of evaluating how efficiently and economically tractors were used. Study results would give us directions for how to improve the operation of tractors, reduce fuel consumption and minimize a harmful impact on the environment.

The objective of the study is to analyze how well the currently working tractor is adapted to the provided work and optimal engine speed as well as what load and fuel consumption are chosen during the operational work of the tractor.

\section{Research Object and Methodology}

For the study, the Massey Ferguson MF 8480 series was chosen. The tractor has been used for road construction works right at the beginning of the operational period. The tractor mainly worked with milling equipment supplied by the company Wirtgen, model WS 2500. The working width of the milling machine is $2.5 \mathrm{~m}$, weight $4200 \mathrm{~kg}$. The working period of the tractor with basic equipment consisted of 527 hours. The tractor was equipped with 'Kleber' rear tires 650/85R38 and 'Kleber' front tires 600/70R28 having the front ballast of $500 \mathrm{~kg}$ and ballast weight on the front pickup hitch of $1500 \mathrm{~kg}$. For the rotation of milling equipment, $1000 \mathrm{~min}^{-1}$ rear PTO speed was used. The work process included pitting and rolling $50 \mathrm{~cm}$ of the clay layer and pitting $10 \mathrm{~cm}$ of the burnt lime layer. These two layers are milling up at a depth of $40-50 \mathrm{~cm}$ employing milling machine WS 2500. Besides milling, work done by the tractor included the roller and the broom.

To analyze engine characteristics for different speed and load modes during the operational period of the tractor, information collected in integrated digital microprocessors was used. The integrated digital microprocessors of Massey Ferguson collect the main operational information such as run intervals combined with engine speed and cyclic fuel injection quantities, including other parameters. Microprocessors accumulate these values for engine run intervals during the operational period of the tractor and represent them in the engine load table and the graph named 'ECU Load Profile' (Fig. 1). When using special Massey Ferguson software and data cable, it was possible to transfer the load profile and data table of this engine to personal computer.

Engine load profile in the table (Fig. 1) and graphic form represents accumulated run intervals (in seconds) for the tractor during its operational period at different engine run modes assorted according to engine speed and cyclic fuel injection quantities. Engine load profile and its data table indicate how long engine might run at the intervals of 700-900, 900-1100, 1100-1300, 1300- 
$1500,1500-1700,1700-1900,1900-2100$ and $2100-$ $2300 \mathrm{~min}^{-1}$. The profile also shows how long the engine ran at cyclic fuel injection quantities of $0-10,10-20,20-$ 30 , etc. reaching $170-180 \mathrm{mg}$.

During the engine probation period, the dependences of engine torque $M_{e}(\mathrm{Nm})$ and hourly fuel consumption $B_{d}$ at different engine speeds are determined. Specific fuel consumption $b_{e}(\mathrm{~g} / \mathrm{kWh})$ shows how much fuel is consumed for the unit of effective engine power output. We can calculate specific fuel consumption $b_{e}$ :

$$
b_{e}=\frac{1000 \cdot B_{d}}{P_{e}} \text {. }
$$

The characteristic curve sheet for MF 8480 engine is made using testing results presented in tractor experimental station 'Cemagref' (France), see OECD Performance... (2008) while cyclic fuel injection characteristics are calculated and presented in Fig. 2.

Engine characteristics presented in Fig. 2 disclose that engine power corresponds to the specified power value or exceeds it $\left(P \geq P_{e}\right)$ when engine speed is in the range of 1700-2200 $\mathrm{min}^{-1}$. The highest power is reached when engine speed is $2000 \mathrm{~min}^{-1}$. At the lowest specif-

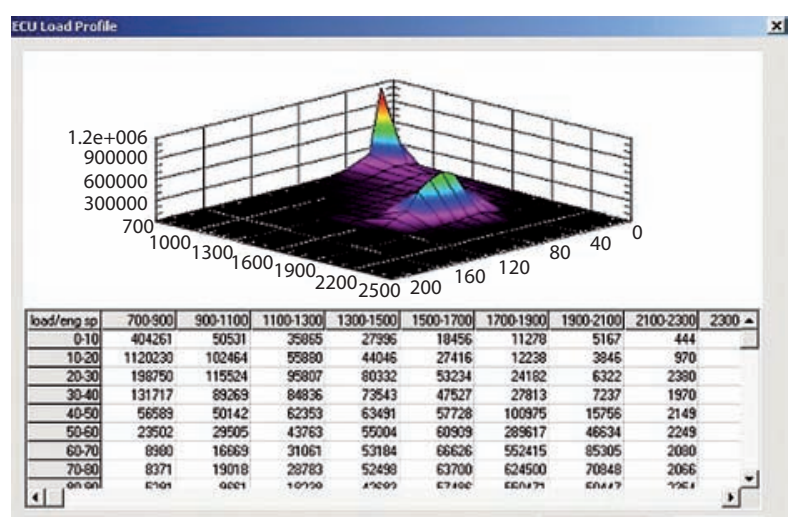

Fig. 1. Engine load profile histogram for Massey Ferguson MF 8480 during the operational period ic fuel consumption when engine speed is in the range of 1050-1350 $\mathrm{min}^{-1}$ engine power reaches $160-190 \mathrm{~kW}$. The specified engine power is reached and the lowest fuel consumption is obtained when engine speed is close to $1700 \mathrm{~min}^{-1}$.

To determine the distribution of engine run time (from ECU Load Profile histograms) during the operational period of the tractor at different engine speeds and load ranges, we need to have a look at engine power dependence on cyclic fuel injection quantities and engine speed. Power is a product of torque and engine velocity:

$$
P_{e}=M_{e} \cdot \omega=0.105 \cdot M_{e} \cdot n \text {. }
$$

The needed engine power dependence on cyclic fuel injection and engine speed can be expressed via engine torque over cyclic fuel injection. From the characteristics of engine torque and cyclic fuel injection presented in Fig. 2 we can draw engine torque dependences on cyclic fuel injection for specific engine run modes (Fig. 3).

Fig. 3 shows that variation in engine torque depends on cyclic fuel injection for specific engine run modes according to the equation:

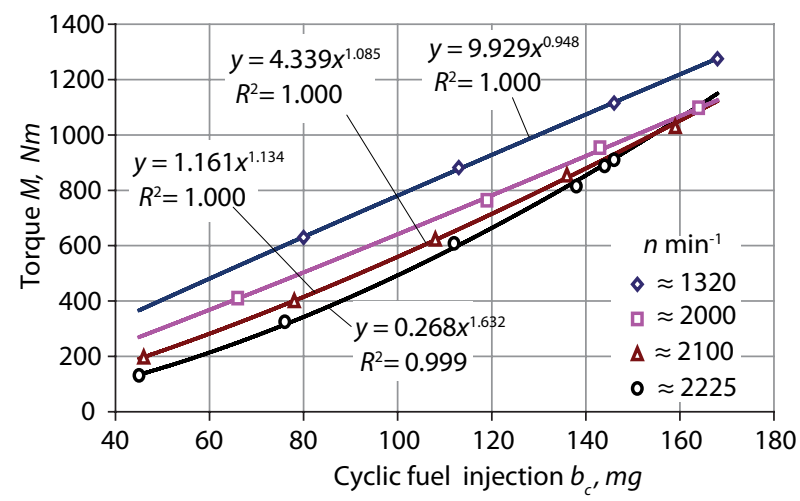

Fig. 3. Engine torque dependences on cyclic fuel injection

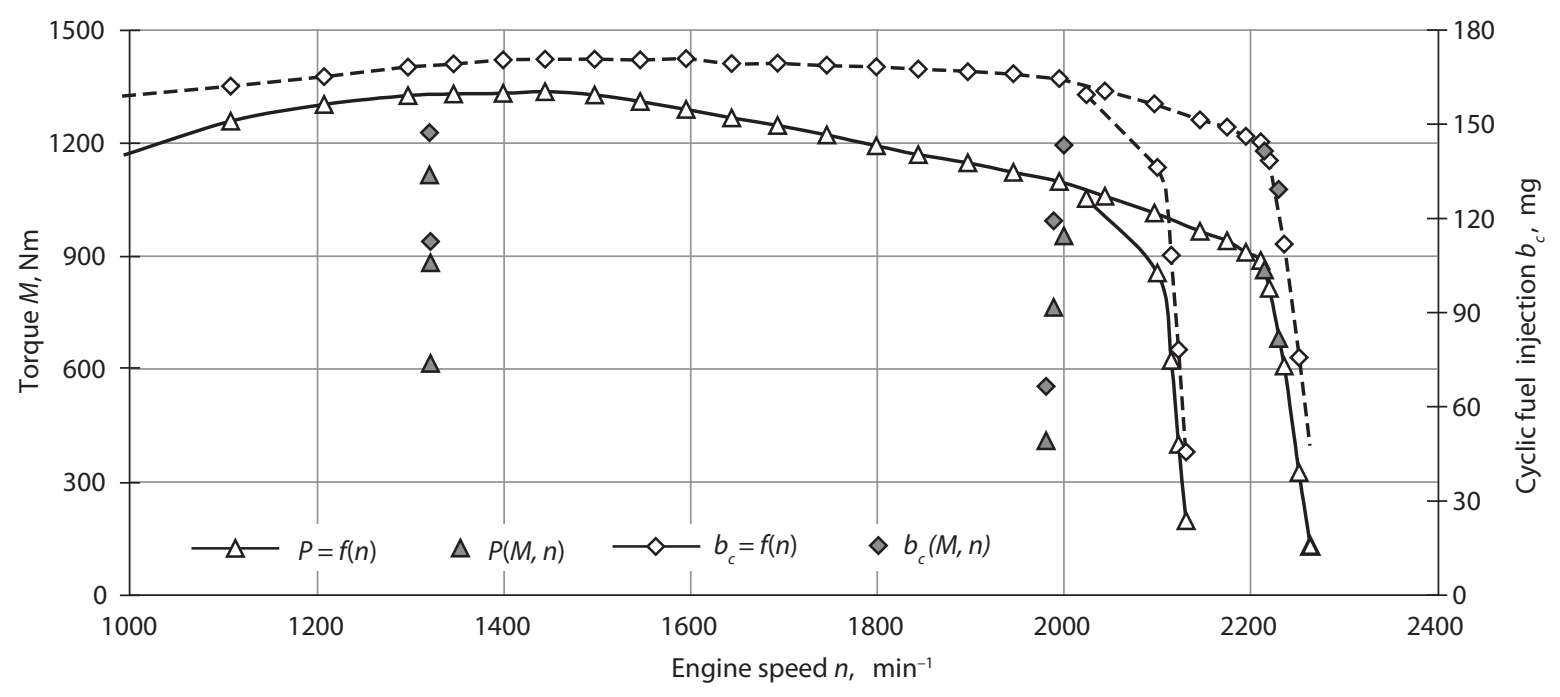

Fig. 2. Engine characteristics for Massey Ferguson MF8480 (OECD Performance... 2008) 


$$
M_{e}=k_{1} \cdot\left(b_{c}\right)^{k_{2}},
$$

where: $k_{1}$ and $k_{2}$ are coefficients that depend on engine load and speed.

To obtain an equation for engine power, speed and cyclic fuel injection, we need to enter a mathematical expression of engine torque to equation 2:

$$
P_{e}=0.105 \cdot k_{1} \cdot\left(b_{c}\right)^{k_{2}} \cdot n \text {. }
$$

The above introduced equation indicates that to calculate engine power, obtaining information on cyclic fuel injection at different engine run modes and coefficients $k_{1}$ and $k_{2}$ is enough.

While knowing cyclic fuel injection quantity $b_{c}(\mathrm{mg})$ at different engine run modes and engine speed $n\left(\mathrm{~min}^{-1}\right)$, we can calculate hourly fuel consumption $B_{d}(\mathrm{~kg})$ of an appropriate engine mode:

$$
B_{d i}=6 \cdot 10^{-5} \cdot \frac{m_{c}}{n_{\tau}} \cdot b_{c i} \cdot n_{i},
$$

where: $m_{c}$ is the number of cylinders; $n_{t}$ is the number of crankshaft revolutions per one cycle of cylinder work.

Tractor fuel consumption during its operational period can be calculated as:

$$
B=\sum_{i=1}^{j} B_{d i} \cdot t_{i},
$$

where: $t_{i}$ is the engine working period at $i$ mode; $j$ is the number of engine working modes registered in histograms.

Research on tractor working mode parameters (engine load / speed modes and fuel consumption) was done according to working histograms (engine run time distribution at different engine speed and cyclic fuel injection) and dependences (Equations) 4, 5 and 6. The run time of the tractor and fuel consumption distribution during the operational period of the working tractor at different engine speeds and load modes were calculated considering from the histograms of the tractor.

The tractor has been applied for road construction works right at the beginning of the operational period. The tractor mainly used milling equipment (model WS 2500) made by the company 'Wirtgen'. For using the tractor (engine load, speed and fuel consumption), the analysis of parameters during work in combination with the examination of milling equipment WS 2500 was performed with reference to the printed 'ECU Load Profile' histograms at the beginning and the end of work. Difference in histograms shows the components of time in seconds at different engine modes by engine speed and cyclic fuel injection during the research period the time of which is one hour and the number of made tests is 5 . Research was done under conditions usual for road construction works. The graphs present the test results of tractor working time and fuel consumption at different engine speeds and power modes within one hour tractor operation using milling equipment WS 2500.

\section{Results and Discussions}

Fig. 4 presents the working time (527 total working hours) of Massey Ferguson MF 8480 tractor. Fig. 5 points to fuel consumption, engine speed and power modes. Figs 6 and 7 show fuel consumption, engine speed and power modes in combination with milling equipment WS 2500.

Fig. 4 shows engine speeds and load modes the investigated tractor has worked considering a noticeably long period of the total working time. The biggest dispersion of tractor working hours is reached at low (700-900 $\mathrm{min}^{-1}$ ) engine speed and low power (up to $20 \mathrm{~kW}$ ) mode. This is an idle speed mode, as presented by Juostas and Janulevičius (2008); Samorodov et al. (Самородов $u$ др. 2004); Stolbov and Efros (Столбов, Эфрос 2008). Within this mode, the tractor worked 277 hours which makes up to $50 \%$ of the total tractor working hours. The engine worked at a high engine speed of $2100-2300 \mathrm{~min}^{-1}$ almost $20 \%$ of the total working hours. Taking into account low and medium engine load $\left(M<50 \% M_{\max }\right)$, the tractor worked a half of its total (about 50) working hours. Also, the tractor worked for 50 hours of the total (257) working hours at high engine speed $\left(n>2100 \mathrm{~min}^{-1}\right)$ and high engine load $\left(M>50 \% M_{\max }\right)$. According the literature review done by Itoh et al. (2008); Zoz et al. (2002); Koval and Samorodov (Коваль, Самородов 2008); Samorodov et al. (Самородов $u$ дp. 2004); Stolbov and Efros (Столбов, Эфрос 2008) the recommendable power of tractors must be not less than $80 \%$ of rated power $\left(P \geq 80 \% P_{e}\right)$. The tractor worked 25 hours at suitable power $\left(P \geq 80 \% P_{e}\right)$ and high engine speed (2100-2300 $\left.\mathrm{min}^{-1}\right)$, whereas for about 40 hours, the tractor worked at a speed of 1900-2100 $\mathrm{min}^{-1}$. The most economical work mode of the tractor is the one at a speed of $1900-2100 \mathrm{~min}^{-1}$ or in a lower engine speed range, as presented by Diesel savings... (2005); Juostas and Janulevičius (2008); Gorodetsky and Titov (Городецкий, Титов 2008); Koval and Samorodov (Коваль, Самородов 2008). Considering а high and medium $\left(P>50 \% P_{\max }\right)$ power mode and the engine speed of $1700-1900 \mathrm{~min}^{-1}$, the tractor worked for 3 hours or $0.7 \%$ of the total working hours.

The distribution of fuel consumption at different engine speeds and power modes during the operational period is presented in Fig. 5. The distribution of fuel consumption at different engine speeds and power modes correspond to engine power and working time under respective modes. More than $700 \mathrm{~kg}$ of fuel or $9 \%$ of the total fuel consumption during $50 \%$ of the total tractor operational period were used at an engine speed of $700-900 \mathrm{~min}^{-1}$ and engine power up to $20 \mathrm{~kW}$. At an engine speed of $1700-1900 \mathrm{~min}^{-1}$ and engine power of $200-220 \mathrm{~kW}$, more than $1885 \mathrm{~kg}$ of fuel or $24 \%$ of the total fuel consumption during $6.4 \%$ of the total tractor operational period were used. Figs 4 and 5 indicate that parallel power at a lower engine speed could be reached with lower fuel consumption. It was obvious that at a power of 200-220 kW and the engine speed range of 1700-1900 $\mathrm{min}^{-1}$, the average hourly fuel consumption 


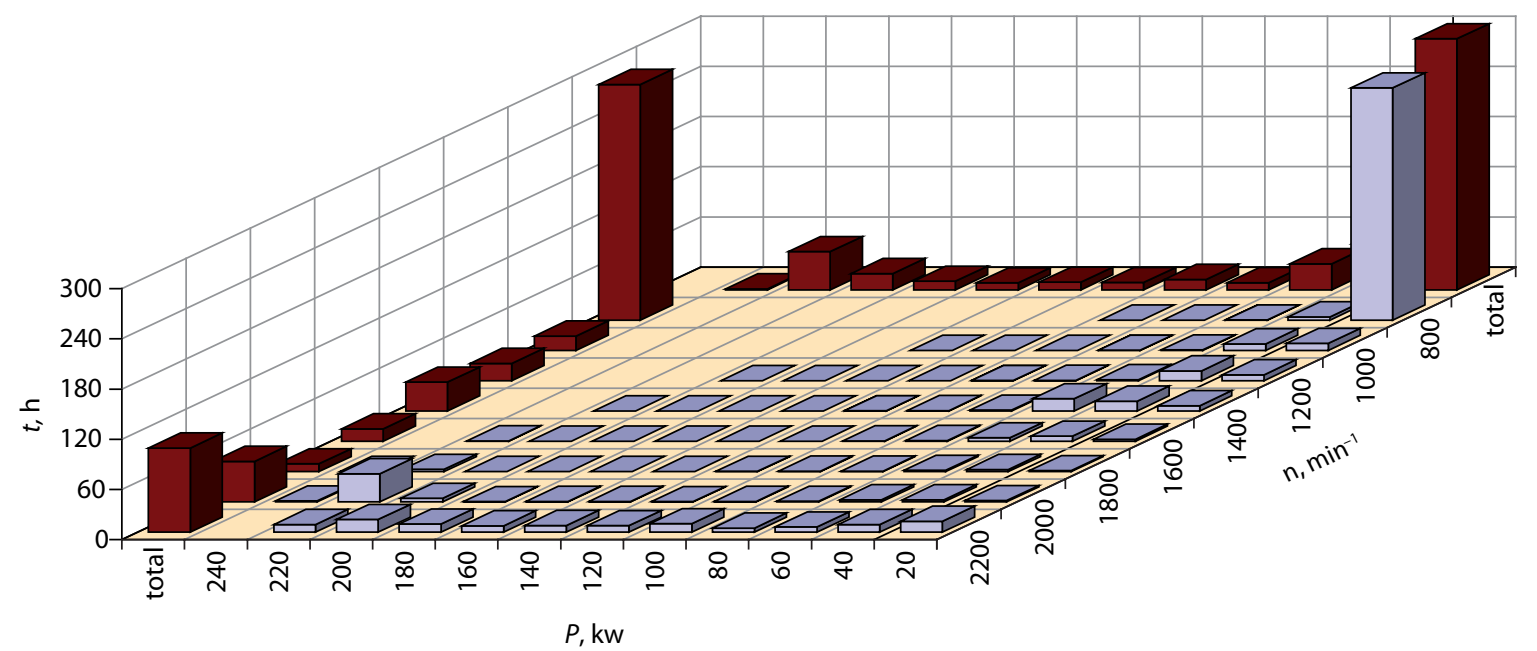

\begin{tabular}{|c|c|c|c|c|c|c|c|c|c|}
\hline & 800 & 1000 & 1200 & 1400 & 1600 & 1800 & 2000 & 2200 & total \\
\hline 20 & 277.43 & 8.30 & 7.03 & 6.34 & 2.34 & 1.16 & 1.48 & 13.06 & 317 \\
\hline 40 & 3.96 & 7.86 & 11.69 & 11.70 & 6.16 & 2.40 & 2.41 & 9.07 & 55 \\
\hline 60 & 0.17 & 0.60 & 1.31 & 14.59 & 4.14 & 1.45 & 2.50 & 6.29 & 31 \\
\hline 80 & 0.02 & 0.27 & 0.39 & 1.01 & 0.84 & 0.48 & 0.74 & 4.86 & 9 \\
\hline 100 & 0.00 & 0.07 & 0.16 & 0.43 & 0.55 & 0.53 & 0.53 & 10.15 & 12 \\
\hline 120 & & 0.01 & 0.08 & 0.18 & 0.14 & 0.27 & 0.34 & 7.70 & 9 \\
\hline 140 & & 0.00 & 0.04 & 0.04 & 0.20 & 0.20 & 0.61 & 7.97 & 9 \\
\hline 160 & & & 0.03 & 0.03 & 0.04 & 0.06 & 0.60 & 7.56 & 8 \\
\hline 180 & & & 0.00 & 0.01 & 0.01 & 0.08 & 0.41 & 9.70 & 10 \\
\hline 200 & & & & 0.09 & 0.01 & 0.03 & 4.17 & 15.17 & 19 \\
\hline 220 & & & & & 0.48 & 2.60 & 33.57 & 9.05 & 46 \\
\hline 240 & & & & & & 0.08 & 1.06 & & 1 \\
\hline total & 282 & 17 & 21 & 34 & 15 & 9 & 48 & 101 & 527 \\
\hline
\end{tabular}

Fig. 4. Distribution of operation hours at different engine performance modes employing Massey Ferguson MF 8480 tractor for 527 hours

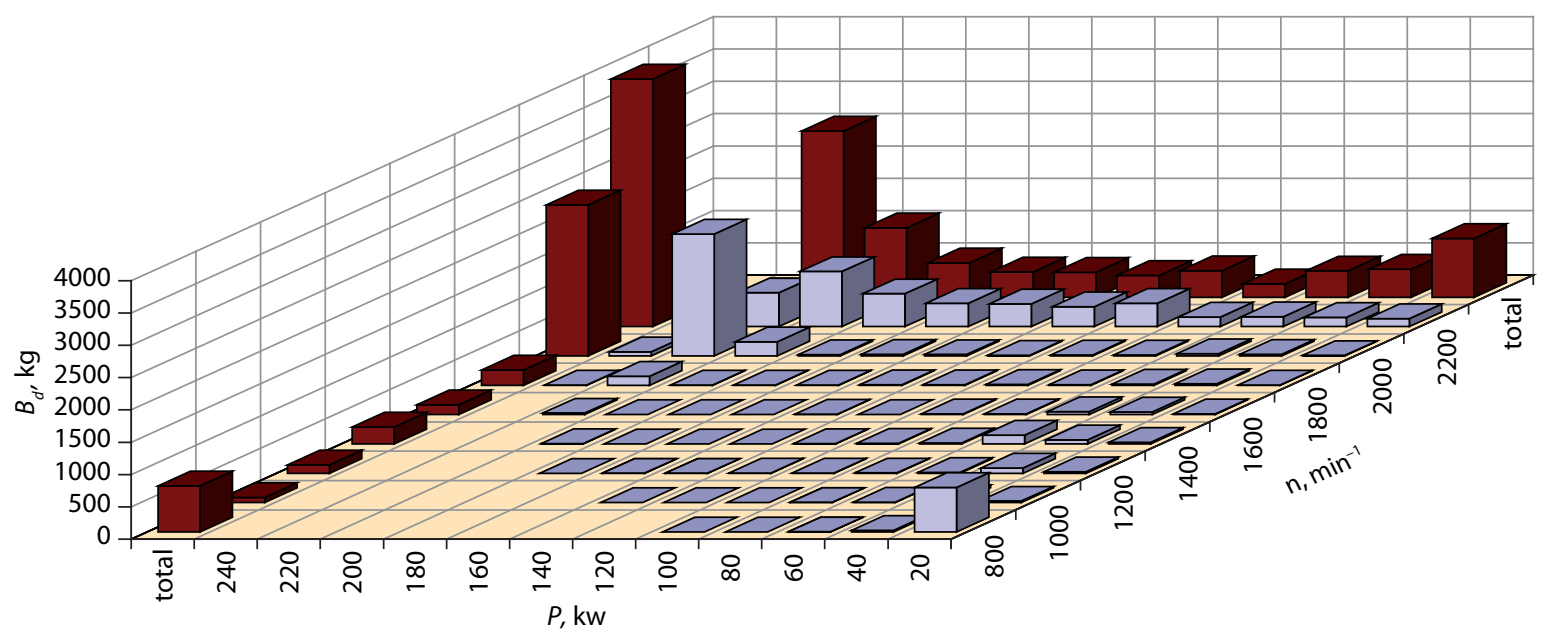

\begin{tabular}{|c|c|c|c|c|c|c|c|c|c|}
\hline & 800 & 1000 & 1200 & 1400 & 1600 & 1800 & 2000 & 2200 & total \\
\hline 20 & 689.21 & 23.43 & 23.95 & 25.21 & 9.69 & 4.86 & 7.86 & 123.72 & 908 \\
\hline 40 & 22.33 & 43.40 & 78.71 & 64.23 & 41.80 & 22.52 & 22.59 & 140.97 & 437 \\
\hline 60 & 1.77 & 6.48 & 13.85 & 135.78 & 44.02 & 19.23 & 35.28 & 152.19 & 409 \\
\hline 80 & 0.29 & 4.05 & 5.83 & 15.17 & 12.41 & 8.62 & 15.71 & 146.31 & 208 \\
\hline 100 & 0.10 & 1.36 & 3.20 & 8.60 & 11.09 & 12.11 & 13.75 & 360.18 & 410 \\
\hline 120 & & 0.36 & 1.93 & 4.64 & 3.47 & 7.90 & 10.65 & 308.44 & 337 \\
\hline 140 & & 0.07 & 0.96 & 1.29 & 4.93 & 6.61 & 21.95 & 350.40 & 386 \\
\hline 160 & & & 1.11 & 1.12 & 1.36 & 2.39 & 24.34 & 361.31 & 392 \\
\hline 180 & & & 0.00 & 0.42 & 0.38 & 3.47 & 18.47 & 508.38 & 531 \\
\hline 200 & & & & 3.82 & 0.35 & 1.52 & 217.89 & 852.69 & 1076 \\
\hline 220 & & & & & 23.53 & 140.02 & 1885.15 & 523.20 & 2572 \\
\hline 240 & & & & & & 4.75 & 63.24 & & 68 \\
\hline total & 714 & 79 & 130 & 260 & 153 & 234 & 2337 & 3828 & 7734 \\
\hline
\end{tabular}

Fig. 5. The distribution of fuel consumption at different engine speeds and power modes during the operational period of Massey Ferguson MF 8480 tractor operated for 527 hours when consumed fuel makes $7734 \mathrm{~kg}$ 


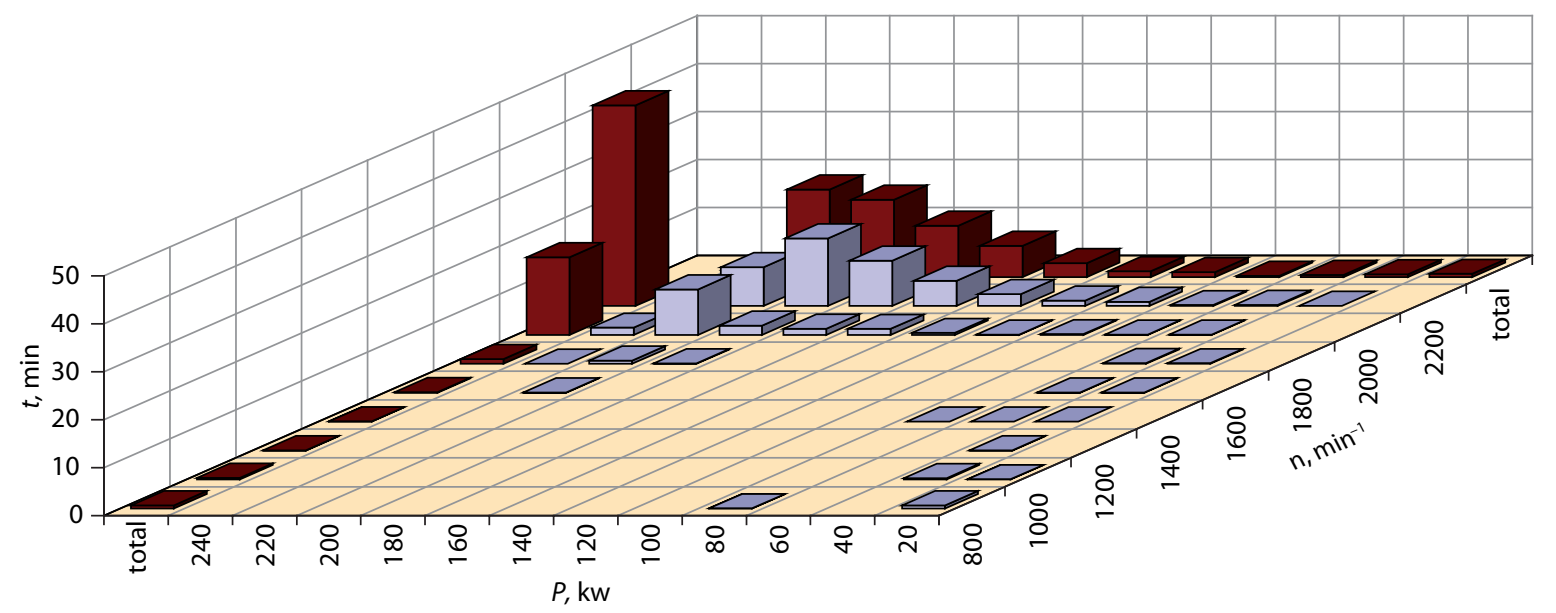

\begin{tabular}{|c|c|c|c|c|c|c|c|c|c|}
\hline & 800 & 1000 & 1200 & 1400 & 1600 & 1800 & 2000 & 2200 & total \\
\hline 20 & 0.63 & 0.05 & 0.00 & 0.00 & 0.00 & 0.00 & 0.00 & 0.00 & 0.68 \\
\hline 40 & 0.00 & 0.30 & 0.03 & 0.02 & 0.05 & 0.12 & 0.00 & 0.05 & 0.57 \\
\hline 60 & 0.00 & 0.00 & 0.00 & 0.02 & 0.03 & 0.13 & 0.05 & 0.22 & 0.45 \\
\hline 80 & 0.02 & 0.00 & 0.00 & 0.02 & 0.00 & 0.00 & 0.05 & 0.18 & 0.27 \\
\hline 100 & 0.00 & 0.00 & 0.00 & 0.00 & 0.00 & 0.00 & 0.15 & 0.88 & 1.03 \\
\hline 120 & & 0.00 & 0.00 & 0.00 & 0.00 & 0.00 & 0.08 & 1.13 & 1.22 \\
\hline 140 & & 0.00 & 0.00 & 0.00 & 0.00 & 0.00 & 0.42 & 2.48 & 2.90 \\
\hline 160 & & & 0.00 & 0.00 & 0.00 & 0.00 & 1.25 & 5.27 & 6.52 \\
\hline 180 & & & 0.00 & 0.00 & 0.00 & 0.00 & 1.27 & 9.43 & 10.70 \\
\hline 200 & & & & 0.00 & 0.00 & 0.08 & 1.95 & 14.08 & 16.12 \\
\hline 220 & & & & & 0.03 & 0.65 & 9.48 & 8.12 & 18.28 \\
\hline 240 & & & & & & 0.03 & 1.52 & & 1.55 \\
\hline total & 0.65 & 0.35 & 0.03 & 0.05 & 0.12 & 1.02 & 16.22 & 41.85 & 60.28 \\
\hline
\end{tabular}

Fig. 6. One hour time distribution in minutes at different engine speeds and power modes during the operational period of Massey Ferguson MF 8480 tractor in combination with milling equipment WS 2500

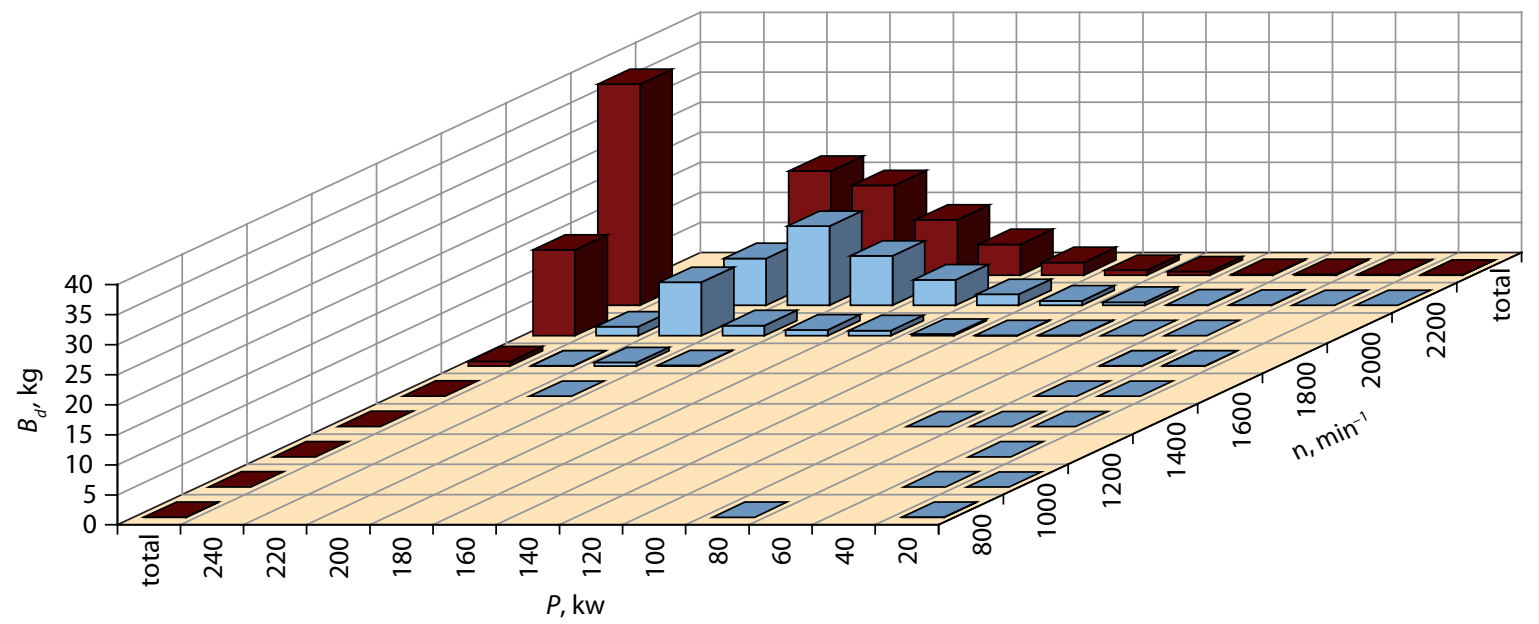

\begin{tabular}{|c|c|c|c|c|c|c|c|c|c|}
\hline & 800 & 1000 & 1200 & 1400 & 1600 & 1800 & 2000 & 2200 & total \\
\hline 20 & 0.027 & 0.003 & 0.000 & 0.000 & 0.000 & 0.000 & 0.000 & 0.000 & 0.03 \\
\hline 40 & 0.000 & 0.032 & 0.004 & 0.002 & 0.006 & 0.020 & 0.000 & 0.014 & 0.08 \\
\hline 60 & 0.000 & 0.000 & 0.000 & 0.003 & 0.006 & 0.030 & 0.013 & 0.087 & 0.14 \\
\hline 80 & 0.005 & 0.000 & 0.000 & 0.005 & 0.000 & 0.000 & 0.019 & 0.092 & 0.12 \\
\hline 100 & 0.000 & 0.000 & 0.000 & 0.000 & 0.000 & 0.000 & 0.066 & 0.531 & 0.60 \\
\hline 120 & & 0.000 & 0.000 & 0.000 & 0.000 & 0.000 & 0.043 & 0.763 & 0.81 \\
\hline 140 & & 0.000 & 0.000 & 0.000 & 0.000 & 0.000 & 0.254 & 1.856 & 2.11 \\
\hline 160 & & & 0.000 & 0.000 & 0.000 & 0.000 & 0.856 & 4.261 & 5.12 \\
\hline 180 & & & 0.000 & 0.000 & 0.000 & 0.000 & 0.958 & 8.239 & 9.20 \\
\hline 200 & & & & 0.000 & 0.000 & 0.070 & 1.687 & 13.177 & 14.93 \\
\hline 220 & & & & & 0.027 & 0.584 & 8.876 & 7.821 & 17.31 \\
\hline 240 & & & & & & 0.032 & 1.511 & & 1.54 \\
\hline total & 0.03 & 0.03 & 0.00 & 0.01 & 0.04 & 0.74 & 14.28 & 36.84 & $\mathbf{5 1 . 9 8}$ \\
\hline
\end{tabular}

Fig. 7. The distribution of fuel consumption within one hour work at different engine speeds and power modes during the operational period of Massey Ferguson MF 8480 tractor in combination with milling equipment WS 2500 
was $54 \mathrm{~kg}$, whereas at parallel power and at higher engine speed range exceeding $2100 \mathrm{~min}^{-1}, 58 \mathrm{~kg}$ of fuel was consumed.

Fig. 6 shows that engine load and the speed of Massey Ferguson MF 8480 tractor using milling equipment WS 2500 was maximal or close to it. The tractor worked at a power of $180-220 \mathrm{~kW}$ and at a higher engine speed range of $2100-2300 \mathrm{~min}^{-1}$ for about $53 \%$ of the total working time which means that the engine worked at the engine speed rated or close to it. The tractor worked at lower (1900-2100 $\left.\mathrm{min}^{-1}\right)$ engine speed and the highest $(210-230 \mathrm{~kW})$ engine power mode for almost $20 \%$ of the total working hours. The rest of working time was distributed in the range of high engine load. Fig. 7 shows that the hourly fuel consumption of Massey Ferguson MF 8480 tractor in combination with milling equipment WS 2500 was $50 \mathrm{~kg} / \mathrm{h}$. Fuel distribution in the work modes of the engine are parallel to the distribution of work time.

When using milling equipment, the tractor engine was loaded under a reasonable level. The engine was loaded $80 \%$ and more considering its total load; however, engine speed mode was not reasonable from an economical point of view. Perhaps fuel consumption could be less selecting higher gear and reducing engine speed, in case it has no influence on the speed of rotating parts. Therefore, it is advisable to make such a study.

Figure 4 discloses that Massey Ferguson MF 8480 tractor was using milling equipment for 100 hours or $20 \%$ of the total working time during the exploitation period. For the he major part (about $80 \%$ ) of the total working time, the tractor worked inefficiently: the engine worked at idle speed and there was plenty of empty driving or work under very low load.

The presented results and their analysis show that studying engine speeds and load modes using information collected in the integrated microprocessors (Electronic Engine Control Units) may reveal the operation quality of the tractor.

\section{Conclusions}

1. Massey Ferguson MF 8480 tractor in combination with milling equipment WS 2500 for road construction works could be loaded $80 \%$ and more. The characteristics of engine speed mode were at a rated speed or close to it. The load modes of such an engine are good for loading the tractor and not optimal from an economical point of view considering speed mode.

2. The tractor in combination with milling equipment worked for $20 \%$ of the total operational period. For the biggest part of working hours (about $80 \%$ ), the tractor was used inefficiently as the engine worked at idle speed and there was plenty of empty driving or work under very low load.

3. The engine ran at idle over $50 \%$ of the total operational period.

4. Studying engine speeds and load modes using information collected in the integrated microprocessors may reveal the operation quality of the tractor.

\section{References}

Diesel savings of $10 \%+$ !. 2005. Profi Tractors and Farm Machinery 9: 48-50.

Itoh, H.; Matsuo, K.; Oida, A.; Nakashima, H.; Miyasaka, J.; Izumi, T. 2008. Aggregate size measurement by machine vision, Journal of Terramechanics 45(4): 137-145. doi:10.1016/j.jterra.2008.09.001

Janulevičius, A.; Juostas, A. 2008. Investigation of tractor working quality by using cumulated information in their modules, in Mechanika 2008: Proceedings of the 13th International Conference, 3-4 April 2008, Kaunas, Lithuania, 180-184.

Juostas, A. Janulevičius, A. 2008. Investigation of tractor engine power and economical working conditions utilization during transport operation, Transport 23(1): 37-43. doi:10.3846/1648-4142.2008.23.37-43

Juostas, A.; Janulevičius, A. 2009a. Evaluating working quality of tractors by their harmful impact on the environment, Journal of Environmental Engineering and Landscape Management 17(2): 106-113.

doi:10.3846/1648-6897.2009.17.106-113

Juostas, A.; Janulevičius, A. 2009b. Investigation of interaction between tractor load and data collected in their modules, in Engineering for Rural Development: Proceedings of the 8th International Conference, 28-29 May 2009, Jelgava, Latvia, 112-117.

Łazarz, B.; Wojnar, G.; Madej, H.; Czech, P. 2009. Evaluation of gear power losses from experimental test data and analytical methods, Mechanika 6(80): 56-63.

Mačiulis, A.; Vasilis Vasiliauskas, A.; Jakubauskas, G. 2009. The impact of transport on the competitiveness of national economy, Transport 24(2): 93-99. doi:10.3846/1648-4142.2009.24.93-99

OECD Performance Test of an Agricultural Tractor. 2008. Test report No. 15588.

Pearson, P.; Bevly, D. M. 2007. Modeling and validation of hitch loading effects on tractor yaw dynamics, Journal of Terramechanics 44(6): 439-450. doi:10.1016/j.jterra.2008.03.001

Pranav, P. K.; Pandey, K. P. 2008. Computer simulation of ballast management for agricultural tractors, Journal of Terramechanics 45(6): 185-192. doi:10.1016/j.jterra.2008.12.002

Raslavičius, L. Bazaras, Ž. 2010. The possibility of increasing the quantity of oxygenates in fuel blends with no diesel engine modifications, Transport 25(1): 81-88. doi:10.3846/ transport.2010.11

Vantsevich, V. V. 2008. Power losses and energy efficiency of multi-wheel drive vehicles: A method for evaluation, Journal of Terramechanics 45(3): 89-101.

doi:10.1016/j.jterra.2008.08.001

Zoz, F. M.; Turner, R. J.; Shell, L. R. 2002. Power delivery efficiency. A valid measure of belt and tire tractor performance, Transactions of the ASAE 45(3): 509-518.

Городецкий, К. И.; Титов, А. И. 2008. Предпосылки формирования рабочих скоростей сельскохозяйственных тракторов [Gorodetsky, K. I.; Titov, A. I. Prescription on choice of the agricultural tractors working speed], Тракторы и сельскохозяйственные машины [Tractors and Agricultural Machines] 11: 30-33 (in Russian).

Коваль, А. А.; Самородов, В. Б. 2007. Крюковая нагрузка и основные технико-экономические показатели колесного трактора на вспашке [Koval, A. A.; Samorodov, V. B. Traction load and main technical-economical parameters 
of wheeled tractor working on ploughed field], Тракторы и сельскохозяйственные машины [Tractors and Agricultural Machines] 6: 15-17 (in Russian).

Коваль, А. А.; Самородов, В. Б. 2008. Пространственнотопологический подход при определении основных технико-экономических показателей колесных тракторов [Koval, A. A.; Samorodov, V. B. Estimation of technical-economical parameters of wheeled tractor by using dimensional-technological method], Тракторы и сельскохозяйственные машины [Tractors and Agricultural Machines] 3: 20-23 (in Russian).

Самородов, В. Б.; Лебедев, А. Т.; Митропан, Д. М.; Сергиенко, Н. Е. 2004. Рациональное агрегатирование тракторов на вспашке [Samorodov, V. B.; Lebedev, A. T.; Mitropan, D. M.; Sergienko, N. E. Reasonable aggregating of tractor on ploughed field], Тракторы и сельскохозяйственные машины [Tractors and Agricultural Machines] 11: 19-22 (in Russian).

Столбов, М. С.; Эфрос, В. В. 2008. Оценка токсичности и эксплуатационной экономичности дизелей самоходных машин [Stolbov, M. S.; Efros, V. V. Estimation of toxicity and working efficiency of diesel engines of automotive machines], Тракторы и сельскохозяйственные машинь [Tractors and Agricultural Machines] 12: 18-20 (in Russian).

Уханов, А. П.; Стрельцов, С. В.; Мустякимов, Р. Н. 2009. Режимы работы двигателя энергосредства с учетом эксплуатационных показателей MTA [Ukhanov, A. P.; Streltsov, S. V.; Mustyakimov, R. N. Engine work modes of tractor aggregate measuring working parameters], Тpaкторы и сельскохозяйственные машины [Tractors and Agricultural Machines] 11: 20-22 (in Russian). 